\title{
The preparation of healthy low calorie ice milk containing green coffee and Stevia
}

\author{
Ragia, O. Mohamed;Hoida,A. M. El-Shazly;Wafaa, A. Mahmoud. Nesreen,M.El-said \\ Food Technology Res. Ins., Agric. Res. Center, Giza, Egypt.
}

\begin{abstract}
This study aimed at the production of low-calorie icy milk by the use of some natural sweeteners like Stevia replacing sucrose in a zero, 50 and 100 percent. Also, the use of green coffee which is considered as one of the richest sources in linoleic acid (one of the essential fatty acids), antioxidant, anticancer, flavoring agent. Therefore, the granule green coffee has been used in a replacement percentage of zero, 1,3 and $5 \%$ of the skimmed milk powder for the production of ice milk. The mixtures as well as the ice products were tested for their chemical, physical, and microbiological properties and also the sensory evaluation. The results demonstrated that there are elevated total solids in the mixtures containing sucrose more than those containing Stevia either the $50 \%$ or $100 \%$ mixtures. In contrast, the contents of fat, protein and ash did not vary, but the caloric content decreased when replacing sucrose by Stevia in a $50 \%$ mixture in all of the treatments. Replacing the skimmed milk with granules green coffee led to variations in the values of specific gravity of all the treatments (mixtures and ice products) and therefore, elevation in the overrun and decrease in the melting resistance using rising replacement percents. The ice products became more preferable in panel test when replacing sucrose by $50 \%$ and adding granules green coffee in a percentage of $3 \%$ of the dry skimmed milk. On the other hand, the treatments sweetened by $100 \%$ Stevia were less accepted by the panel test as regards the characters and appearance. The results revealed also that total bacterial count in the treatments were in the allowed limits and so were the yeasts and moulds while the treatments were totally free of coliform bacteria.
\end{abstract}

Key words: $\quad$ Green coffee -Stevia- ice milk - Essential linoleic fatty acids- healthy food physico-chemical properties - melting resistance and functional foods .

\section{Introduction}

Ice milk is a popular frozen food made from varying mixtures of cream and milk, sweeteners, flavorings and air. The air is beaten into the milk mixture as it freezes, making the final product light and spoonable. Ice cream is a frozen dairy product made by freezing the mixture with agitation to incorporate air and ensure uniformity of consistency (Arbuckle, 1986). Consumers' interest in the relationship between diet and health, increases the demand information on functional foods. Functional foods or dietary components may provide a health benefit beyond basic nutrition. Ice milk has become one of the most acceptable desserts in Egyptian market.

Several resources of non-milk materials have been researched to partially replace mix ingredients in ice cream industry such as soy flour (Hammad et al., 1985), soy milk (Saleem et al., 1989) barley, (Abd-El-Rahman 2003), chufa milk (Abd-El-Rahman and Assem 2004) oil seed protein concentrates (Salama et al., 2007) and, Safflower milk (AbdEl-Rahman and Salama, 2009). 


\section{Ragia, O. Mohamed;Hoida,A. M. El-Shazly;Wafaa, A. Mahmoud. Nesreen,M.El-said}

The green coffee is one of the important functional foods, especially in the Arab countries. Green coffee beans have supplied a new player in the antioxidant arena.

The active constituent in coffee which is responsible for its many health benefits is a compound called chlorogenic acid. It neutralizes free radicals, and addresses the problem of hydroxyl radicals, both of which can lead to cellular degeneration if left unchecked. Chlorogenic acid also helps in regulating metabolism. Compared to green tea and grape seed extract, green coffee bean extract is twice as effective in absorbing oxygen free radicals. An extract of green coffee beans has been found to have a stronger antioxidant effect than the established antioxidants like green tea and grape seed extract. Other benefits of green coffee bean extract include an increase in the effectiveness of pain killers, especially for migraine medications; a reduction in the risk of diabetes; and assisting the body burn a higher proportion of lipids (fats) compared to carbohydrates, which could help with muscle fatigue for athletes and body builders (Veda 2009).

A single-dose study was performed to assess the effect of whole coffee fruit concentrate powder (WCFC), green coffee caffeine powder (N677), grape seed extract powder (N31) and green coffee bean extract powder (N625) on blood levels of brain-derived neurotrophic factor (BDNF). The collected data revealed that treatments with N31 and N677 increased levels of plasma BDNF by about $31 \%$ under these experimental conditions, whereas treatment with WCFC increased it by $143 \%$ (n 10), compared with baseline. These results indicate that WCFC could be used for modulation of BDNF-dependent health conditions (Reyes-Izquierdo, et al., 2012).

Coffee silver skin (CS) is a thin tegument of the outer layer of green coffee beans and a major by-product of the roasting process to produce roasted coffee beans. CS extracts obtained by the treatment of CS with subcritical water at $25-27^{\circ} \mathrm{C}$ were investigated for their antioxidant activity using hydrophilic oxygen radical absorption capacity ( $\left.\mathrm{H}-\mathrm{ORAC}\right)$ and 1,1-Diphenyl-2-picryl hydrazyl (DPPH) radical scavenging capacity assays. The antioxidant activity increased with increasing the extraction temperature and the highest activity was observed with the extracts obtained at $270^{\circ} \mathrm{C} . \mathrm{High}$ correlation $(\mathrm{R}=0.999)$ was observed between $\mathrm{H}-\mathrm{ORAC}$ and $\mathrm{DPPH}$ values for the CS extracts. High correlation of the antioxidant activity was also observed with protein and phenolic contents in the extracts. The CS extracts could be useful as a good source of antioxidative materials (Narita and Inouye 2012).

Epidemiological studies regarding the associations of tea and coffee consumption with esophageal cancer (EC) risk are still inconsistent. Random effects model was used to pool the odds ratios (OR). A borderline significantly inverse association of highest vs. non/lowest coffee consumption against $\mathrm{EC}$ risk was found $(\mathrm{OR}=0.88 ; 95 \% \mathrm{Cl}: 0.76,1.01)$. These data showed that both green tea and coffee consumption, but not black tea consumption, have protective effects on esophageal cancer (EC) (Zheng et al., 2013).

Recently, coffee consumption has been related to decreased risk of type 2 diabetes mellitus (DM) among those with high levels of serum $y$-glutamyltransferase (GGT). The association between coffee and glucose tolerance was examined and determined by a $75 \mathrm{~g}$ oral glucose tolerance test, and the effect modification of serum GGT on the association. Statistical adjustment was made for age, body mass index, smoking, alcohol use, leisure-time physical activity, green tea consumption, parental diabetes, hospital, and rank in the Self-Defense Forces. Men with normal glucose tolerance, isolated impaired fasting glucose (IFG), isolated impaired glucose tolerance (IGT), combined IFG/IGT, and type 2 DM were studied. The prevalence odds of isolated IGT, combined IFG/IGT, and type 2 DM, but not of isolated IFG, decreased with increasing consumption of coffee. An inverse association with coffee was observed for isolated IGT in both low ( $\leq 40 \mathrm{IU} / \mathrm{L}$ ) and high (>40 IU/L) GGT groups, and for combined IFG/IGT and type 2 DM in the latter group. They concluded that Coffee drinking is protective against glucose intolerance. A possible effect modification of GGT on the coffee-DM association warrants further studies (Hiramatsu et al., 2013). 
Green coffee contains antioxidants which are good for the heart and arteries. Studies suggest that moderate coffee-drinkers have an $80 \%$ lower risk of Parkinson's disease, a $25 \%$ lower risk of colon cancer, a $50 \%$ lower risk of kidney stones and an $\mathbf{8 0 \%}$ lower risk of cirrhosis of the liver. In addition, it has recently been shown that coffee may cut the risk of type II diabetes and that a decaffeinated extract of green coffee may be effective in controlling weight (Smart City, 2010). Uto-Kondo, et al. (2010) hypothesized that coffee may enhance reverse cholesterol of high- density lipoprotein (HDL).

Elizabeth Barrett et al (1994) reported that Lifetime caffeinated coffee intake equivalent to two cups per day is associated with decreased bone density in older women who do not drink milk or dairy product on a daily basis.

A study was conducted to assess the efficacy of green coffee extract (GCE) as a supplement for weight loss, using data from human clinical trials. Electronic and non electronic searches were conducted to identify relevant articles, with no restrictions in time or language. The results revealed a significant difference in body weight in GCE compared with placebo (mean difference: $-2.47 \mathrm{~kg} ; 95 \% \mathrm{Cl}:-4.23,-0.72$ ). The magnitude of the effect is moderate. It was concluded that the results from these trials are promising (Onakpoya et al., 2011).

Overweight and obesity have been considered as a serious health concern (Ana et al., 2011). Many types of sweeteners are available and have been used for the purpose of weight loss. Stevia is considered as natural and safe sweetener. Stevia plant leaves have sweet taste 300 times more than sucrose. It is highly stable to heat and acid . Besides that it is suitable for diabetics and hyperglycemia (Chalopathiri, et al., 1997).

\section{Materials and Methods}

\section{Materials}

Green coffee seeds were obtained from local market. Milk cream was obtained from Faculty of Agriculture, Cairo University, Egypt.

Skimmed milk powder, sugar and vanilla were purchased from local market. Gelatin was purchased from the Egyptian Company for Milk products and additives.

Stevia was purchased from the Egyptian Company for milk products and additives.

\section{Methods}

Green coffee seeds was Milled in the blender to obtain coffee grinding.

\section{Preparation of ice milk mixes}

Three replicates of ice milk mixes were prepared using Stevia $50 \%$ and $100 \%$ from sucrose and green coffee granules as a substitute for skimmed milk powder at the levels of, 1, 3 and $5 \%$ respectively. All mixes were standardized to contain $5 \%$ fat and $11 \%$ solids no fat (S.N.F) using fresh cream and skimmed milk powder. $15 \%$ sugar, and $0.5 \%$ gelatin were added. All mixes were heat treated at $85^{\circ} \mathrm{C}$ for $5 \mathrm{~min}$., then cooled to $5^{\circ} \mathrm{C}$ and $0.2 \%$ vanilla was added. There after, the mixes were aged at $6^{\circ} \mathrm{C}$ for $24 \mathrm{hr}$ before freezing as reported by Arbuckle (1986) using hard ice cream machine (Taylor Co. USA). The resultant ice milk was filled into PVC cups (cap. $60 \mathrm{ml}$ ) covered and hardened in deep freezer at $-16^{\circ} \mathrm{C}$ ) for 24 hours before analysis. The composition of six different ice milk mixes is shown in (Table1). 
Tale (1):

Formula of ice milk mix made by substitution of milk solids not fat (MSNF) by green coffee granules and sucrose by Stevia. (Kg|100Kg mix).

\begin{tabular}{|c|c|c|c|c|c|c|c|c|c|c|}
\hline \multirow{2}{*}{ Ingrediant } & \multirow{2}{*}{ Control } & \multicolumn{3}{|c|}{$1 \%$} & \multicolumn{3}{|c|}{$3 \%$} & \multicolumn{3}{|c|}{$5 \%$} \\
\hline & & T1 & T2 & T3 & T4 & T5 & T6 & T7 & T8 & T9 \\
\hline Cream & 12.5 & 12.5 & 12.5 & 12.5 & 12.5 & 12.5 & 12.5 & 12.5 & 12.5 & 12.5 \\
\hline Sucrose & 15.0 & 15.0 & 7.5 & - & 15.0 & 7.5 & - & 15.0 & 7.5 & - \\
\hline Stevia & - & - & 0.4 & 0.8 & - & 0.4 & 0.8 & - & 0.4 & 0.8 \\
\hline Skimmed milk & 12.2 & 11.2 & 11.2 & 11.2 & 9.2 & 9.2 & 9.2 & 7.2 & 7.2 & 7.2 \\
\hline Gelatin & 0.5 & 0.5 & 0.5 & 0.5 & 0.5 & 0.5 & 0.5 & 0.5 & 0.5 & 0.5 \\
\hline Green coffee & - & 1.0 & 1.0 & 1.0 & 3.0 & 3.0 & 3.0 & 5.0 & 5.0 & 5.0 \\
\hline Venilla & 0.2 & 0.2 & 0.2 & 0.2 & 0.2 & 0.2 & 0.2 & 0.2 & 0.2 & 0.2 \\
\hline Water & 59.6 & 59.6 & 66.7 & 73.8 & 59.6 & 66.7 & 73.8 & 59.6 & 66.7 & 73.8 \\
\hline
\end{tabular}

T1: $100 \%$ sucrose $+1 \%$ green coffee

T3: $100 \%$ Stevia $+1 \%$ green coffee

T5: $50 \%$ sucrose $+50 \%$ Stevia $+3 \%$ green coffee

T7: $100 \%$ sucrose $+5 \%$ green coffee

T9: $100 \%$ Stevia $+5 \%$ green coffee
T2: $50 \%$ sucrose $+50 \%$ Stevia $+1 \%$ green coffee

T4: $100 \%$ sucrose $+3 \%$ green coffee

T6: $100 \%$ Stevia $+3 \%$ green coffee

T8: $50 \%$ sucrose $+50 \%$ Stevia $+5 \%$ green coffee

Chemical analysis:-

Fresh skimmed milk, skimmed milk powder and cream were analyzed for their total solids (TS), fat, total protein and ash according to the methods outlined A.O.A.C, 2000). Total carbohydrates were calculated by difference.

The prepared mixes and ice milk were analyzed for their titratable acidity, $\mathrm{pH}$ value as reported by Ling (1963). Specific gravity was determined at $20^{\circ} \mathrm{C}$ using pycenometer as described by (Winton, 1958), weight per gallon (Burke, 1947). Melting resistance of the resultant ice milk was examined according to Reid and Painter (1933). The overrun of the resultant ice milk was examined according to Arbuckle (1986). Viscosity was determined using a viscometer LV model DV-IIL according to Johson et al., (1995). The freezing point for the mixes was tested as in Mrshall et al., (2003).

\section{Microbiological analysis:-}

The ice milk products were microbiological examined for total bacterial count, mould and yeasts count and coliform group according to the American Puplic Health Assoc. (A.P.H.A., 1994).

\section{Sensory evaluation:-}

The organoleptic properties of each patch of ice milk were evaluated according to Nelson and Troat (1951).

\section{Results and Discussion}

\section{Chemical composition of ice milk mix:-}

Table (2) illustrates the chemical composition of ice milk mix made by substitution of milk solids not fat (MSNF) with Stevia. The results indicated that the control had the maximum value of total solids (T.S) while T1, T4 and T7 had the higher values of total solids than the other treatments. The Fat content in T9 had the higher values (5.50) than the 
other treatments, while the control had the lower value of fat. Total protein was 4.80 in the control sample and 4.66 in treatment T3 while the other treatments had the less values of total protein. The results of Ash content had the higher value $(0.97)$ in the control sample while T9 had the lower value $(0.78$ (this results may be due to the composition of green coffee. The content of Carbohydrates in the control sample was the higher value than the other treatments, while T3 was the lower value.

Slight and variable differences in Calorie Values (K.Cal) content between the treatments were detected, It was noticed that T1and $\mathrm{T} 7$ had the higher value than the other treatments.

Table (2):

Composition of ice milk mixtures made by substitution of milk solids not fat (MSNF) by green coffee granules and sucrose by Stevia.

\begin{tabular}{l|c|c|c|c|c|c}
\hline Treatments & $\begin{array}{c}\text { T.S } \\
\%\end{array}$ & $\begin{array}{c}\text { Fat } \\
\%\end{array}$ & $\begin{array}{c}\text { Total Protein } \\
\%\end{array}$ & $\begin{array}{c}\text { Ash } \\
\%\end{array}$ & $\begin{array}{c}\text { Carbohydrates } \\
\%\end{array}$ & $\begin{array}{c}\text { Calories } \\
\text { Values (K.Cal) }\end{array}$ \\
\hline Control & 34.10 & 5.10 & 4.80 & 0.97 & 22.70 & 150.5 \\
\hline T1 & 33.80 & 5.15 & 4.60 & 0.95 & 22.65 & 156.0 \\
\hline T2 & 27.18 & 5.15 & 4.60 & 0.93 & 16.50 & 105.0 \\
\hline T3 & 23.58 & 5.20 & 4.66 & 0.82 & 12.90 & 70.3 \\
\hline T4 & 33.00 & 5.30 & 4.30 & 0.92 & 22.55 & 154.0 \\
\hline T5 & 27.27 & 5.30 & 4.32 & 0.85 & 16.80 & 117.0 \\
\hline T6 & 23.52 & 5.30 & 4.29 & 0.83 & 13.10 & 71.5 \\
\hline T7 & 32.72 & 5.40 & 4.00 & 0.90 & 22.50 & 150.4 \\
\hline T8 & 27.80 & 5.40 & 3.99 & 0.79 & 16.90 & 112.0 \\
\hline T9 & 23.48 & 5.50 & 4.00 & 0.78 & 13.20 & 70.1 \\
\hline
\end{tabular}

Properties of ice milk mixes:- Acidity and $\mathrm{pH}$ content are considered as important factor in developing the flavor and texture of ice cream. Table (3) illustrates the properties of ice milk mixes made with green coffee and Stevia. It can be observed that acidity was higher in treatment T1, T4 and control samples than the other treatments, while $\mathrm{pH}$ values had the opposite trend to the same treatments.

The results showed that Viscosity (C.P) had the higher values in treatment T7 while T3, T6 and T9 had the lower values compared with the all treatments، These results may be due to the percentage of green coffee. The differences of specific gravity between treatments were clear, it differed from 0.9305 to 1.041 . The less value of Specific gravity was in control treatment and the highest was in treatment T7. Freezing Point $\left({ }^{\circ} \mathrm{C}\right)$ changed from -2.40 to -3.70 between treatments. 


\section{Ragia, O. Mohamed;Hoida,A. M. El-Shazly;Wafaa, A. Mahmoud. Nesreen,M.El-said}

Table (3):

Properties of ice milk mixtures made by substitution of milk solids not fat (MSNF) by green coffee granules and sucrose by Stevia.

\begin{tabular}{l|c|c|c|c|c}
\hline Treatments & Acidity & $\mathrm{pH}$ value & Viscosity & Specific gravity & $\begin{array}{c}\text { Freezing } \\
\text { Point }\left(\mathrm{c}^{\circ}\right)\end{array}$ \\
\hline Control & 0.21 & 6.41 & 35 & 0.9305 & -2.40 \\
\hline T1 & 0.21 & 6.42 & 40 & 0.9469 & -2.41 \\
\hline T2 & 0.22 & 6.40 & 30 & 0.9467 & -2.61 \\
\hline T3 & 021 & 6.40 & 25 & 0.9465 & -2.90 \\
\hline T4 & 0.22 & 6.41 & 45 & 1.0070 & -3.00 \\
\hline T5 & 0.23 & 6.39 & 30 & 1.0020 & -3.20 \\
\hline T6 & 0.23 & 6.39 & 25 & 1.0010 & -3.20 \\
\hline T7 & 0.20 & 6.37 & 55 & 1.0410 & -3.40 \\
\hline T8 & 0.22 & 6.36 & 35 & 1.0320 & -3.70 \\
\hline T9 & 0.20 & 6.32 & 35 & 1.0110 & -2.90 \\
\hline
\end{tabular}

\section{Properties of resultant ice milk}

Table (4) shows the Properties of resultant ice milk of 9 treatments and one control. The results indicated that the highest value of specific gravity was in the control sample (0.6301) while the lower value was in treatment T9. It was noticed that there was a slight differences between treatments T1 to T8 .

It was found that treatment T7 had the highest value of the overrun\%, control and T3 samples had the lowest values of overrun \%. Weight gallon of control treatment had the highest value (5.2582 (while all treatments had decreased of weight gallon compared with the control samples.

Properties of resultant ice milk was affected by melting resistance which was divided in to 3 portions : loss of melting after $30 \mathrm{~min}$., loss of melting after $45 \mathrm{~min}$., and loss of melting after $60 \mathrm{~min}$. Results indicated that the control samples had the highest value of melting resistance after $45 \mathrm{~min}$. while treatment T4 had the highest value after $30 \mathrm{~min}$., and treatment T9 was the highest value (50) after $60 \mathrm{~min}$ 
Egypt. J. of Nutrition and Health Vol. 7 No. 1 (2012)

Table (4): Properties of resultant ice milk.

\begin{tabular}{|c|c|c|c|c|c|c|}
\hline \multirow[t]{2}{*}{ Treatments } & \multirow[t]{2}{*}{$\begin{array}{r}\text { Specific } \\
\text { gravity }\end{array}$} & \multirow[t]{2}{*}{ Overrun } & \multirow[t]{2}{*}{ Weight gallon } & \multicolumn{3}{|c|}{$\begin{array}{l}\text { Melting resistance } \\
\text { (loss \% after) }\end{array}$} \\
\hline & & & & 30min. & $45 \mathrm{~min}$. & 60min. \\
\hline Control & 0.6301 & 40.05 & 5.2582 & 17.50 & 30.4 & 42 \\
\hline T1 & 0.6212 & 50.08 & 5.1839 & 15.90 & 28.0 & 41 \\
\hline T2 & 0.6210 & 45.01 & 5.0738 & 13.20 & 27.0 & 39 \\
\hline T3 & 0.6200 & 40.05 & 5.0609 & 12.20 & 26.0 & 38 \\
\hline T4 & 0.6100 & 60.82 & 5.0905 & 32.60 & 24.2 & 46 \\
\hline T5 & 0.6099 & 50.20 & 5.0800 & 30.00 & 23.5 & 42 \\
\hline T6 & 0.6090 & 42.30 & 5.0700 & 28.80 & 23.1 & 40 \\
\hline T7 & 0.6000 & 71.44 & 5.0070 & 15.80 & 29.9 & 48 \\
\hline T8 & 0.5980 & 48.30 & 5.0040 & 13.20 & 24.0 & 49 \\
\hline T9 & 0.5900 & 42.05 & 5.0010 & 12.10 & 23.2 & 50 \\
\hline
\end{tabular}

\section{Microbial Count of ice milk}

The microbial count of ice milk (total count, Lactic acid bacteria $\left(10^{6}\right)$, coliform bacteria, mould and yeast) with green coffee and Stevia was illustrated in (Table 5). It was clear that ice milk samples with added green coffee had less microbial count than control samples. This behaviour may due be to the antioxidant characteristics of green coffee . Control samples had the highest number of total count bacteria $\left(14 \times 10^{7}\right)$.

The results showed that treatment T1 had the highest number of Lactic acid bacteria $\left(9 \times 10^{5}\right)$ while T4 had the lowerest one. Coliforms bacteria were not detected in all samples, there results may due to the antioxidant effect of green coffee (Veda,2009). While mould and yeasts were detected in treatments T1, T2, T3, T8 and T9 samples.

Table (5):

Microbial count (CFUI ml) of resultant ice milk.

\begin{tabular}{l|c|c|c|c}
\hline \multicolumn{1}{c|}{ Treatments } & $\begin{array}{c}\text { Total count } \\
\times\left(10^{7}\right)\end{array}$ & $\begin{array}{c}\text { Lactic acid } \\
\text { bacteria } \times\left(10^{6}\right)\end{array}$ & $\begin{array}{c}\text { Mould \&Yeast } \\
\times\left(10^{1}\right)\end{array}$ & $\begin{array}{c}\text { Coliform } \\
\times\left(10^{1}\right)\end{array}$ \\
\hline Control & 14.0 & 7.5 & N.D & N.D \\
\hline T1 & 9.0 & 9.0 & 2.1 & N.D \\
\hline T2 & 9.0 & 4.0 & 2.0 & N.D \\
\hline T3 & 10.0 & 6.0 & 3.0 & N.D \\
\hline T4 & 12.0 & 2.6 & N.D & N.D \\
\hline T5 & 11.0 & 3.0 & N.D & N.D \\
\hline T6 & 11.0 & 4.5 & N.D & N.D \\
\hline T7 & 9.0 & 5.0 & N.D & N.D \\
\hline T8 & 8.0 & 3.0 & 3.0 & N.D \\
\hline T9 & 7.0 & 4.5 & 2.0 & N.D \\
\hline
\end{tabular}




\section{Organoleptic Scores of ice milk:-}

The acceptability of ice milk depends on its appearance and sensory properties, (Flavor, Body and texture, Melting quality, Appearance). Among these, flavor has 45 points out of total 100 points for evaluation, body and texture 30 points, melting quality 10 points and appearance 15 points. Therefore, flavor is the most important characteristic concerning the judge and consumer as well. Sensory evaluation of ice milk had been shown in Table (6) ).

Flavor: The flavor score of treatment T7 ice milk was higher than the other treatments. The results were (44.60) in T7 ice milk, while T9 was lower .

Body and Texture: The high score of texture was in treatments T4 and T5, while the lower score of ice milk was in treatment T9.

Melting quality : The control sample of ice milk had higher score than all treatments while T9 had the lower score .

Appearance: The control had distinctly higher score than the other treatments and T9 had the lower score of appearance ice milk.

Table (6):

Organoleptic scores of ice milk treatments.

\begin{tabular}{l|c|c|c|c|c}
\hline \multicolumn{1}{c|}{ Property } & Flavour & $\begin{array}{c}\text { Body } \\
\text { Texture }\end{array}$ & $\begin{array}{c}\text { Melting } \\
\text { quality }\end{array}$ & Appearance & Total \\
\hline Treatments & 45 & 30 & 10 & 15 & 100 \\
\hline Control & 42.24 & 25.57 & 8.83 & 15.0 & 91.44 \\
\hline T1 & 42.47 & 25.58 & 8.60 & 14.0 & 90.65 \\
\hline T2 & 43.00 & 25.58 & 8.59 & 14.0 & 91.12 \\
\hline T3 & 42.90 & 25.50 & 8.60 & 13.0 & 90.00 \\
\hline T4 & 44.57 & 27.40 & 7.78 & 14.0 & 93.75 \\
\hline T5 & 44.57 & 27.40 & 7.90 & 13.5 & 93.37 \\
\hline T6 & 44.60 & 26.00 & 7.00 & 12.0 & 89.60 \\
\hline T7 & 43.12 & 25.83 & 7.10 & 11.0 & 87.05 \\
\hline T8 & 43.00 & 25.00 & 6.50 & 11.0 & 85.50 \\
\hline T9 & 41.00 & 23.00 & 6.00 & 10.0 & 80.00 \\
\hline
\end{tabular}




\section{References}

A.O.A.C. (2000):

Official Methods of Analysis. $16^{\text {th }}$ Ed. Associated of Official Analytical Chemists. Inc. Arlington. Virginia. USA.

Abd-El-Rahman, A.H. (2003).

The use of barley extract in the manufacture of ice cream. Egyptian J. Dairy 31: 411-419

Abd-EL-Rahman, A. H. and Assem, H. N. (2004):

The production of a new ice milk. Egypt .J.Agric.Res,82:191-203.

Abd-El-Rahman, A.H. and Salama, M.W. (2009).

Processing of healthy ice milk. Egyptian J. Agric.Res.,87(5):1453-1462.

American Public Health Association (APHA) (1994)

Standard Methods for Microbiological Examination of Food. 16th ed. pp. 843-845, Washington,D.C.,USA.

Ana, C. L. ;Katrarnia, M. S. ;Mary, L. G. and Karen, E. P. (2011):

Beliefs and practices related to weight status, feeding, and the Development of child Overweight Public. Health Nursing Vol. (28), No 2,P 107-118.

Arbuckle, W.S.(1986).

Ice cream. Fourth Edition, van Nostrand Reinhold Co. New York.

Burke, A.D. (1947).

Practical Ice Cream. The Olsen publishing Co. Milwaukee, Wisconsin.

Chalopathiri, M. V. ; Thimegowda, S. S. and Prasad, T. G. (1997):

Natural non-caloric sweetener Stevia (Stevia rebaudiana) a future crop. Indian 14:247-350.

Elizabeth Barrett-Connor, MD; Jae Chun Chang; Sharon L. Edelstein, ScM(1994):

Coffee-Associated Osteoporosis Offset by Daily Milk Consumption JAMA. 1994;271(4):280-283

Hammad, Y.A.; Hamzawi, L.F.; Zedan, A.N. and Khader, A.E. (1985).

The use of defated soy flour in ice cream manufacture. Minufiya J. Agric. Research. 10: $833-840$.

Hiramatsu, T. ; Tajima, O. ; Uezono, K. ; Tabata, S. ; Abe, H. ; Ohnaka, K. and Kono, S. (2013):

Coffee consumption, serum $Y$-glutamyltransferase, and glucose tolerance status in middle-aged Japanese men. Br J Nutr. 14:1-6.

Johnson, J.R.; Braddock R.J. and Chen (1995).

Kinetics of ascorbic acid loss and nonenzymatic browning in orange juice serum: Experimental rate constants. J. Food Sci., 60:502.

Ling, E.R. (1963).

A Text Book of Dairy Chemistry. Vol. 2, 3rd Ed. Chapman and Hall. Ltd., London, New York. 
Marshall, R.T.; Douglas G.H. and Richard, R.W. (2003).

Ice cream $6^{\text {th }}$ Ed. Pp. 44-49\& 139-142. Kluwer Academic/Plenum Publishers, New York, USA.

Narita, Y. and Inouye, K. (2012):

High antioxidant activity of coffee silverskin extracts obtained by the treatment of coffee silverskin with subcritical water. J. Agric. Food Chem. 26;60(38):9631-41.

Nelson. J.S. and Trout, GM. (1951):

Judging of Dairy Product, $3^{\text {rd }}$, cd. The Olsen publishing. Co Milwauke U.S.A.

Onakpoya, I. ; Terry, R. and Ernst, E. (2011):

The use of green coffee extract as a weight loss supplement: a systematic review and meta-analysis of randomised clinical trials. Gastroenterology Research and Practice; 2011:382852. [PubMed.

Reid, W. H. E. and Painter, W.E. (1933).

The freezing properties stability and physical quality of chocolate ice cream. Missouri, Agric. Exp. Sta. Bul. 185.

Reyes-Izquierdo, T. ; Nemzer, B. ; Shu, C. ; Huynh, L. ; Argumedo, R. ; Keller, R. and Pietrzkowski, Z.

(2012):

Modulatory effect of coffee fruit extract on plasma levels of brain-derived neurotrophic factor in healthy subjects. Biosci Biotechnol Biochem. 23;76(12):2329-31.

Salama, H.; Hammad, Y.; Hamzawi, L.F. and Hassan, Z.M. (2007).

Functional properties of some oil seed protein concentrate and its utilization in healthy functional imitation ice milk. Proc. $10^{\text {th }}$ Egyptian Conf. Dairy Sci.\& Techn. 503-516.

Saleem, R.N.,; Shaker, K.A. and El-Waeely, S.M. (1989).

The use of soy milk in ice cream mixes. Egyptian J. Dairy Sci., 17: 281-288.

Smart City, (1997):

Extract $200 \mathrm{mg}$ - Weight green Coffee control - Super Smart www.supersmart.com/en--Green-Coffee-Extract200-mg--Weight- control--0388.

Uto-Kondo H, Ayaori M, Ogura M, Nakaya K, Ito M, Suzuki A, Takiguchi S, Yakushiji E, Terao Y, Ozasa H, Hisada T, Sasaki M, Ohsuzu F, Ikewaki K(2010).

Coffee consumption enhances high-density lipoprotein-mediated cholesterol efflux in macrophages.Circ Res. 2010 Mar 5;106(4):627

Veda, (2009):

Morning Drink An Anti AgingPosted in 5th Veda on November 13, 2009

Winton, A.L. (1958).

Analysis of Foods. $3^{\text {rd }}$ printing P.D. John Wiley and Sons Inc. New York.

Zheng, J. S. ; Yang, J. Fu YQ; Huang. T. and Huang, Y. J. , Li D. (2013):

Effects of Green Tea, Black Tea, and Coffee Consumption on the Risk of Esophageal Cancer: A Systematic Review and Meta-Analysis of Observational Studies. Nutr Cancer. 65(1):1-16. 
تحضير مثلج لبنى صحى منخقض السعرات الحرارية يحتوى على القهوة الخضراء و الأستافيا

راجية عمر يوسف، هويدا الثاذلى ، وفاء محمود ، نسرين محمد السعيد

معهد بحوث تكنولوجيا الأغذية، مركز البحوث الزراعية، الجيزة، مصر.

الملغص العربي

تهذف هذة الدراسة لانتاج مثلج لبنى منذفض الطاقة باستخدام بعض المحليات الطبيعية مثل الاستافيا كبديل للسكروز بنسبة

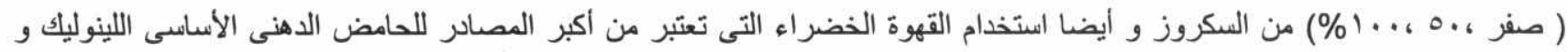

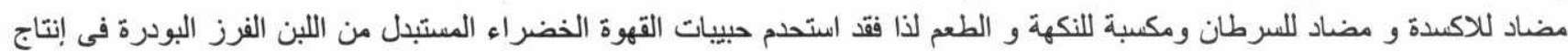

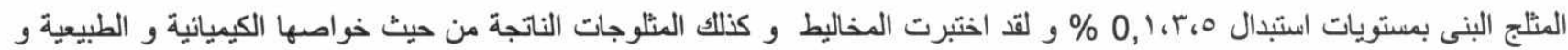

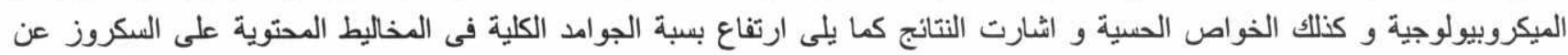

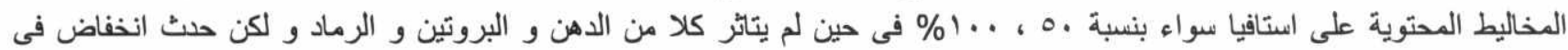
السعر ات من .0 \% عند استبدال السكروز بالاستافيا فى كل المعاملات .

وانت نسب الاستبدال اللبن المجفف بحبيبات القهوة الخضر اء إلى اختلافات فى قيم الكثافة النوعية لكل من المخاليط و المثلوجات

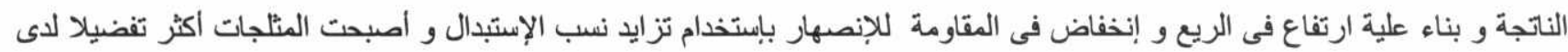

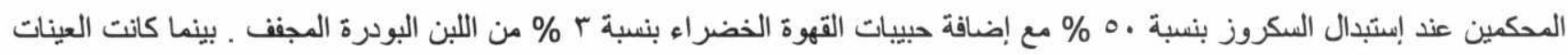

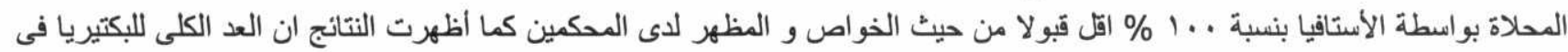

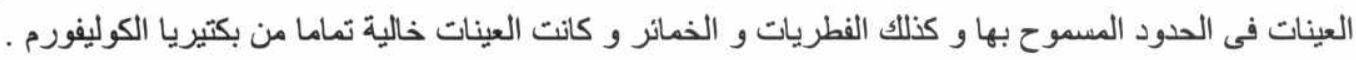

